\title{
Type, Function, Aesthetic and Value of Madurese Pesantrensyi'ir
}

\author{
Jam'an $^{1}$, Wahyudi Siswanto ${ }^{2}$, Muakibatul Hasanah ${ }^{3}$, A. Syukur Ghazali ${ }^{4}$ \\ Indonesian Language Education Study Program \\ Post-Graduate Program of State University of Malang
}

\begin{abstract}
This research focused on several issues i.e. type, function, aesthetic and value of Madurese Pesantrensyi'ir. This research appliedHermeneutic circle and etnography as the support while the data was analysed qualitatively. This research concluded that the highly-valued syi'ir of Islamic boarding school comprising moral and spiritual learning elaborated in type, function, aesthetic and values of syi'ir.
\end{abstract}

Keywords: type, function, aesthetic, values, syi 'ir, Madurese Islamic Boarding School

\section{Research Context}

Islamic boarding school or the so-called pesantrenis a place for religious education. It gives major contribution in religious development with literary values. Generally, syi'ir was written by old students in their spare times. At that time, there was no Islamic School in an Islamic Boarding School like today. The students who stayed in the dorm or lodging house in mullah's residence complex had much time to compose a syi'ir. Nevertheless, most of the mullahs did it too (Jonge, 1989:194).

One of literary works grown around the circle of Madurese Islamic Boarding School is called "pesantren literature". The characteristics of the literature are as follows: (1) the language of pesantren literature is Arabic-written Madurese, (2) pesantren literature is sometimes written in Arabicpegon , (3) it was born more less in the beginning of 19 century and rapidly grown around 19 to 20 centuries, (4) pesantren literature was in the form of oraltradition containing moral values, fiqh, tawheed, tasawuf, theology, nasheed, and so forth, (5) usually, pesantren literature was read in scientific halaqah (circle), certain ritual ceremony and performed as art performance at times, and (6) pesantren literature was a bit influenced by Middle East, Arabic, or Persian literature (Basuki, 1989; Thohir, 1997).

Pesantren literature is impressively known as spoken literature which are remembered and continually spreaded across generations. Pesantren literature is in the form of spoken and written tradition collected in a collection of literary work or religious book in the spoken form which grew and evolved in pesantren's surrounding. One of types of pesantren literature is syi'ir. One of pesantren literature aspects is religious literature comprising prayers such as dzikr, hizb, and wifiq.

The form of syi'ir was similar to syi'ir in Malay's literature which consisted of 1) four lines in each stanza, 2) aaaa rhymed syi'ir, 3) no lineswhich meaning is unrelated to the next lines (sampiran), and neither is the content lines, but the four lines are directly connected and 4) part of the illustration or long story is in a stanza of pesantren literature.
The example of Madurese syi'ir of pesantren:

Manussa bâkal matě

Dâ' ka Allah abâli polě

Toa ngodâ ta' elěpělě

Amal bâgus ghâbâi leollě

\section{Translation}

Human will die

To Allah they will return

No favoritism between young and old

Good deeds will equip

Kaulâ ngarang dâ' si iran

Se aessè parengattan,

Ka angghui enga' dâ' patè

Salanjhânga mâ' ngastètè

\section{Translation}

I composed the syi'ir

Which warns you

To remember the death

Forever to be careful

The writers of the ancient syi'irs were hardly found. Research about pesantren's syi'ir has not been widely done by both foreign and Indonesian researchers. In regards to this issue, pesantren syi'iris such a "jungle" as well as "treasure" of the ancestor's heritage which needs serious sort out. Therefore, this research was intended to rescue the repertoire of written literary works from pesantren, either in Madurese or those which has been interpreted into Bahasa.

According to the literature study which has been through by the researcher, it turned out that the most complete and intact research on pesantren syi'irhas never been done by previous researchers. Hence, this research tried to dig up problems about type, function, aesthetic and values of Madurese Islamic Boarding School or pesantrensyi'ir.

The strong reasons underlying the need of a research on syi'ir are as follows: (1) the transcripts of syi'ir has not been divulged so that many of them are neglected, (2) concerning the aspect of content, the transcript of syi'ir contains advices, education, and moral values so that it is rich in advantage especially for modern people nowadays who 


\section{International Journal of Science and Research (IJSR) \\ ISSN (Online): 2319-7064}

Index Copernicus Value (2015): 78.96 | Impact Factor (2015): 6.391

experienced moral decadence along with the rise of permissive and anarchistics and (3) to save the highly-valued assets of pesantren in the form of character and spiritual learning which are expressed in the form of syi'ir. Relying on the importance of the content of pesantren syi'r, the researcher was interested to conduct a research on the type, function, aesthetic and values of Madurese pesantrensyi'ir.

\section{Research Focus}

According to the three reasons aforementioned, a problem which is interesting enough to invetigate is on "how is the type, function, aesthetic and values of Madurese pesantrensyi'ir?"

\section{Research Objectives}

This research aimed at exploring, describing and analyzing the type, function, aesthetic, and values of Madurese pesantrensyi'ir.

\section{Research Method}

On the research of Madurese pesantren syi'irfocusing in the study of type, function, aesthetic and values, the researcher used qualitative research method. In line with a statement by Bogdan and Biklen (1998: 4-7), the characteristics of qualitative research are (1) using the research background as the source of data collection which is scientific, (2) the data is descriptive, (3) putting more concern on the importance of process aside from result, (4) the analysis is done inductively, and (5) meaning is the most essential since the feature of the data, source of data, data analysis, and technique of data analysis showed the characteristics of qualitative research. In consonance with a notion by Cresswell (2010:27), he affirmed that a research is categorized qualitative if the researcher attempts to (1) collect the meaning, (2) focus on single concept, (3) validate the findings accurately, and (4) interpret the data. This research studied the type, function, and aesthetic values of Madurese Islamic Boarding School by carrying out a data collection, data analysis, drawing conclusion/verification, and checking the validation of the data. Interpretation on the type, function, aesthetic and values of Madurese pesantren syi'irwas done by employing Hermeneutic circle method which was initially started by (1) a thorough,deep readingand the process of describing, continued by (2) repetitive reading to discover a comprehensive understanding and (3) determining final meaning or understanding towards the text.

The data source of this research was categorized as document. The texts of Madurese pesantren syi'ircollected in dzikrul maut and the record result from the students in various prayer-houses and Madurese Islamic Boarding School were set as the data sources. The data of this research was in the form of spoken literature or oral tradition of Madurese pesantren syi'irwritten originally in Madurese language but in Arabic letters. The data were then translated or transcribed by the researcher from Arabic letters to alphabet and then translated into Bahasa in order to help the researcher in analyzing the data (interpretation). Aside from document, the data were also sourced from the interview result with public figure or Madurese literature lovers and supporters.

Data collection is the data obtained through the main instrument that was the researcher himself which was in charge of collecting and translating the data of literature in the form of Madurese pesantren syi'irin order to ponder on the type, function, aesthetic, and values of Madurese pesantrensyi'ir. The steps of collecting the data are as follows: (a) reviewing the text of Madurese pesantren syi'irwhich had been transcribed and translated by the researcher, reading the text deeply and repetitively in order to gain the meaning of type, function, aesthetic and values in comprehensive way, (b) reviewing the research result and written transcription related to culture and Madurese literature, (c) performing a deep interview with public figures, the elders and mullahs who read Madurese pesantren syi'irby using writing stuffs,recorder (either audio or visual) and (d) collecting the data through several techniques i.e. recording, observing, interviewing, and reviewing document. As has been stated by Emzir and Rohman (2015: 219-220), the practice of research on spoken literature must be initially transcibed prior to further analysis. The transcription result is in the form of raw data which must be processed by the researcher. Next, the data are collected, systematized and analyzed in regards to the research problems.

The data analysis in this research would be conducted by grounding on the basic data analysis of flow model developed by Miles and Hubberman (1992: 15-20) which consists of three steps i.e. (1) data reduction, (2) data presentation, and (3) drawing conclusion or verification. The data analysis was begun by eliminating the data which are irrelevant with the research problem, whilst the relevant data were analyzed. The process of data reduction was performed to all data collcted in each cycle of research action. The main reference is reducting the data consisting research problems and type of data needed for explaining the problems. The data presentation was done by exposing all the reducted data. The process of drawing conclusion and verification were carried out by interpreting the meaning of the data presented. Before drawing the final conclusion, temporal conclusion was done initially. The interpretation result of the meaning from the data presented was verified in order to generate final conclusion which is trustworthy. The process od verification was done by checking the validity of the data which had been determined. Regarding the finding or the result of this research, discussion with the experts competent in Madurese culture was done. The data acquired from each technique of data collection will complete to one another.

The next step is validation checking on the data findings in order to draw a conclusion based on data reduction and presentation which had been done. The three things aforementioned are such a unity intertwining each other which were carried out during and after the data collection in parallel form to build general knowledge called analysis. Data collection was actually precondition to perform data reduction, data presentation, and drawing conclusion. 


\section{International Journal of Science and Research (IJSR) \\ ISSN (Online): 2319-7064}

Index Copernicus Value (2015): 78.96 | Impact Factor (2015): 6.391

\section{Research Result}

\section{a. Type of Madurese PesantrenSyi'ir}

The type of Madurese pesantren syi'iron its rhythm usage based on sound yields an analysis result in the following. First, the repetition of assonance rhyme in Madurese pesantren syi'irwas found on vocal sounds $/ \mathrm{u}, \mathrm{a} /$ and /o,a/ in several words. The existence of these repetitive vocal in Madurese pesantren syi'irmakes it easy to be spoken and listened to. Second, the repetition on rhyme of alteration in Maduresepesantren syi'irwas found in consonant sounds in each words in the same line as well as in different lines. Since the syi'ir is in Madurese Language, it was rarely found an alteration of consonant sound in the beginning of words of the same line. Third, there was found a perfect rhyme which indicated similarities in the last syllable of each line of a stanza. Fourth, the imperfect rhyme was found on several last syllable in each line of a stanza, for instance, the last rhyme of the first line was ťe, while the second, third, and fourth lines had $l \breve{e}$ as their last rhyme.

The type of Madurese pesantren syi'iron its rhyme usage based on word location in lines generates ananalysis as follows. First, there was found a series of similar words in the initial rhyme of Madurese pesantren syi'irin the beginning of line in a stanza. There was also found in two sequential lines in a stanza. This revealed that there was an emphasize of deep meaning which was used in purpose by the writer as an expression of words aside from the purpose of aesthetic. Second, in the middle rhyme of Madurese pesantrensyi'ir, identical words were found sequentially in the middle of lines in a stanza. Third, almost all lines in the last rhyme of Madurese pesantren syi'irmostly used final rhymrs. The similarities of the last sound did not have to be consisted of vocal or consonant syllable. The most important consideration is that it has the same last sound in each line. Perceived from the ordered last rhyme in each line of each stanza, it was called five strands as appeared in a-a-a-a and b-b-b-b rhymed syi'ir.Fourth, broken rhyme in Madurese pesantren syi'irindicated the non-rhymed word or last sound which implies random last sound, as shown in a stanza below:

Tolang dhâghing loddhus kabbhi

É pokol ta' è ambuwi

Tangĕssa pon raja kĕnĕ’

Akantha monyĕna embi'

The last sound $i-i-e-i$ in the four lines above is the evidence that it has distinctive rhyme. This was caused by the demand of syi'ir content although, literally, if the distinction of sounds or in the last rhymes it could cause ghindul (awkward) when spoken. Fifth, twin rhymes in Madurese pesantren syi'irpoint out sequential twin rhymes two each on the last rhyme with identical rhythm but in different lines it was either in the form of vocal or consonant, with a-a-b-b or c-c-d-d-e-e patterns. Sixth, parallel rhyme in Madurese pesantren syi'irrevaled repetitive similar words in each line of a stanza which appeared in order either in the beginning, middle or last of the line.

The content of each stanza and each group of stanza on each title of Madurese pesantrensyi'ir, although the title of each group was different, generally, the overall stanzas still showed a continuous connection, i.e. the connection of content in Madurese pesantrensyi'ir. As well as lines in Madurese pesantrensyi'ir, they have interrelated content so that it constructs intact stories thoroughly in Madurese pesantrensyi'ir.

The use of diction in the structure of Madurese pesantren syi'irresults an analysis as follows: 1) denotation, 2) connotation, 3) synonym, 4) antonym, 5) general and particular dictions, and 6) polysemy. Other than the use of diction, there are also a) the use of language style based on sentence structure which covers 1) parallelism, 2) repetition, b) the directness/indirectness meaning from a language style comprise 1) rethoric style which consists of (a) alliteration, (b) assonance, (c) euphimism, (d) litotes, (e) hyperbole, and 2) figurative language such as (a) simile, (b) metaphore, and (c) personification.

\section{b. Function of Madurese pesantrensyi'ir}

The research result on function of Madurese pesantren syi'iris as follows: 1) recreational function, (a) in denotative meaning it means amusing, whilst (b) in connotative meaning it means eliminating several feelings such as bothersome or anxiety, 2) educational function which comprises (a) function on religious education covering human's obligation to serve Allah, the impacts of being disobedience human towards Allah, and motivation for human beings to keep their faith in order to equip them in the afterlife, (b) function on moral education which aimes at making people be realized and encouraged in doing good deeds, giving advices to make them be able to distinct which one is good and which one is not good to do, growing values of honesty among the society so that they can really compare which one is true and false, giving impression and messages, making people intended to maintain good deeds and avoid bad deeds, and (c) function on social education so that people could perform good attitudes among their closest relatives and others, have good interaction with others because one day everyone will need each other for certain cases. Another function of social education is to evolve an attitude of helping each other, spreading guidelines for all society members, and create empathy.

\section{c. The Aesthetic of Madurese pesantrensyi'ir}

The analysis result on the aesthetic of Madurese pesantren syi'ircovers all kinds of Language usage specifically to gain certain effects, that is the aesthetic itself. The concept of aesthetic is part of the aesthetic. Aesthetic in Madurese pesantren syi'iris indicated by the availability of (1) the aesthetic of advice, (2) the aesthetic of humour, (3) the aesthetic of emotion i.e. a) moving atmosphere, b) death atmosphere, and (4) the aesthetic of passion such as a) tense feeling, b) the harsh torture of death underground, and c) an atmosphere of the cruelty happened in hell.

\section{d. Values of Madurese pesantrensyi'ir}

The analysis of Madurese pesantren syi'iron the aspect of values generated a result as follows: 1) religious value, covering (a) values of faith covering (1) a confession on the existence of the new reborn day, (2) a confession on the existence of torture in hell, (3) a confession on the existence of heaven's people, (4) the existence of satanic disturbance 


\section{International Journal of Science and Research (IJSR) \\ ISSN (Online): 2319-7064}

Index Copernicus Value (2015): 78.96 | Impact Factor (2015): 6.391

during death's door, (5) the confession of the separation of phisical and spiritual body, (b) worship value consisting of (1) an instruction to worship Allah faithfully, 2) a command to stay distance from sin/repent, 3) a command to prepare a provision to live in the afterlife, 2) Philosophical value (a) an instructionto always remember the death, (b) to seek for knowledge as provision in this world and the afterlife and 3) social values.

\section{Closing}

It can be concluded that Madurese pesantren syi'iris a literary work of the ancient students during their stay in a boarding school. Islamic boarding school is such a place to learn religious education which mostly develops an aspect of religiosity particularly Islam. Students living in a boarding school around mullah's regency complex would have much time to compose syi'ir. Besides, there were many mullahs who also wrote syi'ir. Syi'ir which grew in the boarding school surrounding in Madura was called pesantren literature. Pesantren literature was perceived as oral literature which was remembered and bequeathed across generations and developed around pesantren environment which loads prayers such as dzikr, hisb, and wifiq. The writers of the ancient syi'ir was hardly found.

This research was intended to save the repertoire of literary works originally from Madurese Islamic boarding school (pesantren) which are highly valued as they contain character building and spiritual learning which were expressed through syi'ir.In relation to that, the researcher could describe and discover problems about type, function, aesthetic, and values of Madurese pesantrensyi'ir. The findings of this research is expected to be one of inputs for the development of syi'ir theory particularly in a research about syi'ir as one aspect of literature study. On the other hand, with full of respect, this research was also expected to enrich the repertoir of theory and reference in developing a research theory of syi'ir in the field of literature. Therefore, it is suggested for the devotees of this field of study, future researchers and language teachers to take advantage from findings of this research in regards to type, function, aesthetic and values of Madurese pesantren syi'irfor the sake of the knowledge development of literature. This study can also be used as the reference and further perfection in order to improve the theory in syi' ir research and literatures in general.

\section{Reference}

[1] Alwi, Hasan. 2003. Kamus Besar Bahasa Indonesia. Jakarata: Balai Pustaka.

[2] Badudu, j.s. 1983. Sari Kesusastraan Indonesia 1. Bandung: CV. Pustaka Prima

[3] Basuki, Anshari. 1989. "Sastra Pesantren" dalam Lembaran Sastra. Semarang: Faculty of Letters UNDIP.

[4] Bogdan, Robert C. \& Sari Knopp Biklen. 1998. Qualitative Research in Education: An Introduction to Theory and Method. Boston: Allyn \& Bacon.

[5] Brunvend, Jan Harold. 1968. The Study of American Folklore: An Introduction. Yew York. W.P. Norton \& Co. Inc.
[6] Creswell, Joh, W. 2010. Research Design, Pendekatan Kualitatif, Kuantitatif, dan Mixed. Yokyakarta: Pustaka Pelajar.

[7] Dananjaya, James. 1982. Folklor Indonesia: Ilmu Gosip Dongeng, dan lain-lain. Jakarta: Pustaka Utama Grafiti.

[8] Effendy, Moh. Hafid. 2014. Gramatika Bahasa Madura, Tinjauan Deskriptif tentang Pramasastra Bahasa Madura. Pamekasan: STAIN Pamekasan Press.

[9] Emzir. Rohman, Saifur. 2015. Teori dan Pengajaran Sastra. Jakarta: PT. Raja Grafindo Persada.

[10] Gie, The Liang. 1976. Garis Besar Estetika (Filsafat Keindahan).Yokyakarta: Karya Kencana.

[11] Huberman, A. Michael. 1992. Analis Data Kualitatif. Jakarta. UI-Press

[12] Jonge, Huub de. 1989. Agama, Kebudayaan, dan Ekonomi (Studi-studi Interdisipliner Tentang Masyarakat Madura. Jakarta: CV. Rajawali Pers.

[13] Kusmayati, A.M. Hermien. 2000. Arak-arakan (Seni Pertunjukan dalam Upacara Tradisional di Madura). Yokyakarta: Tarawang Press.

[14]Luxemburg, Jan Van. 1987. Tentang Sastra. Translation by Akhadiati Ikram 1991. Jakarta: Intermasa.

[15] Ma'arif, Samsul. 2015. The History of Madura. Yokyakarta: Araska.

[16] Moleong, Lexy J. 2005. Metodologi Penelitian Kualitatif. Bandung: PT. Remaja Rosdakarya.

[17] Ong, Walter J.1982. Orality and Literacy: the technologizing of the word. London and New York: Methuen.

[18] Palmer, Richard E. 2005. Hermeneutika : Teori Baru Mengenai Interpretasi. Translated by Munsur Hery and Damanhuri Muhammad. Yogyakarta: Penerbit Pustaka Pelajar.

[19] Pawitra, Adrian. 2009. Kamus Lengkap Bahasa Madura Indonesia. Jakarta: Dian Rakyat.

[20] Ratna, Nyoman Kutha. 2009. Teori, Metode, dan Teknik Penelitian Sastra. Yokyakarta: Pustaka Pelajar.

[21]Rifai, Mien, Ahmad. 2007. Manusia Madura Pembawaan, Perilaku, Etos Kerja, Penampilan, dan Pandangan Hidupnya seperti Dicitrakan Peribahasanya, Yogyakarta: Pilar Media.

[22] Sadik, Sulaiman. 2013. Selintas tentang Bahasa dan Sastra Madura. Pamekasan: Bina Pustaka Jaya.

[23] Sumaryono, E. 1999. Hermeneutika: Sebuah Metode Filsafat. Yogyakarta: Kanisius.

[24] Suroso, Puji Santoso. 2009. Estetika (Sastra, Sastrawan \& Negara). Yokyakarta: Pararaton Publishing.

[25] Teeuw, A. 1984. Sastra dan Ilmu sastra : Pengantar Teori Sastra. Jakarta : Pustaka Jaya. 